\title{
Assessment of timely initiation of breastfeeding and associated factors among mothers who have infants less than six months of age in Gunchire Town, Snnpr, Ethiopia 2019
}

Ephrem Yohannes Roga ( $\square$ efremjohn27@gmail.com )

Wollo University https://orcid.org/0000-0002-3448-8310

Tsegaye Tesfaye Hailu

Wolkite University

Tadesse Gebreegziabher Kahsay

Wollo University

Research article

Keywords: Timely, Breastfeeding

Posted Date: March 3rd, 2020

DOI: https://doi.org/10.21203/rs.2.14944/v2

License: (a) (1) This work is licensed under a Creative Commons Attribution 4.0 International License.

Read Full License 
The authors have withdrawn the journal submission associated with this preprint and requested that the preprint also be withdrawn. 